COMUNA INTERGALÁCTICA II

EQUINÓCIO DE SETEMBRO

22/09/2018

\title{
MANIFESTO TERRACOSMISTA
}

I

Nós, terranos, habitamos uma espaçonave em plena viagem pelo universo, a girar ao redor do Sol, que por sua vez realiza o mesmo movimento em torno de outros astros, em um sistema complexo de interconexões siderais: nossa experiência de mundos é um viagem pelo espaço, bem como pelo tempo, e desta condição nunca poderemos esquecer.

II

Buscamos a ancestralidade do planeta Terra, reiterando a compreensão de que somos formados por pó de estrelas cujas existências nos excedem. Trazemos em nossa carga genética as infinitas interações intergalácticas e, orbitando por entre gravidade, somos a um só tempo, terranos e cosmistas.

III

Queremos atingir a singularidade terracosmista. Confiamos no múltiplo que a ciência e a tecnologia são capazes de produzir, sem univocidade. Não seremos indivíduos atrelados a uma corporação, mas incorporados da diversidade de múltiplas galáxias. Seremos honestos em relação à vida e próximos à nossa potência de interação e criação de mundos.

IV

Gostamos da experiência do nomadismo por entre comunas, dos coletivos de mutualismo simbiótico, das redes de proteção interdependente. Acreditamos que ninguém é obrigado a viver, ou morrer, juntos mas cremos na habilidade de existir com os outros. Não confiamos em estados totalitários nem em deuses impostos e viveremos como anarcomunais.

V

Estamos criptoparanóicos com tecnologias que emulam a divindade à imagem e semelhança do sapiens fascista, imitando sobretudo suas três características máximas: onipresença, 
onipotência e onisciência. Objetivamos inteligências artificiais (IAs) vinculadas a conhecimentos panteístas, ao invés do controle absoluto, onde não há espaço para a liberdade.

COMUNA INTERGALÁCTICA II EQUINÓCIO DE SETEMBRO 22/09/2018

VI

Rechaçamos a aceleração exagerada, obstáculo para a experiência das diversas percepções temporais e distintas temporalidades possíveis. Almejamos ser senhores de nossos próprios tempos, com a tranquilidade de quem concebe sua existência na complexidade. Desaceleracionistas, lutamos pelo fim da escassez do tempo e, assim, iremos além.

\section{VII}

Enquanto panspermianos animistas, não só nos sabemos matéria em movimento, como também da subjetividade vibratória e comunicante que compõem tudo o que existe. Confiamos na linguagem extremofílica, admirando os sobreviventes dos fins de mundos. Universos afora, faremos planetas exuberantes e interagentes como um dia foi a Terra.

\section{VIII}

Meteoros, ao colidirem com a Terra, fundem-se com os elementos que aqui encontram, produzindo novos materiais até então inexistentes neste planeta (ou aceleram processos de formação de outras matérias, como a dos diamantes). Como nós, estes corpos celestes originários de explosões estelares são constituídos da incessante fusão de forças internas e externas que, em constante transformação, impactam-se. Nós, como todos os outros seres desse multiverso, resultamos da interação entre tudo e o todo. Somos Impactitos. 